\title{
ARTIKELEN
}

\section{Werkzame en toekomstbestendige wetgeving ${ }^{*}$}

\author{
E. Niemeijer \& P.W. van Wijck
}

\section{Inleiding}

Recht beïnvloedt gedrag, en dat is ook de bedoeling. Het recht heeft echter niet automatisch de beoogde gedragseffecten. De vraag welke gedragseffecten het recht in werkelijkheid heeft, is een kernvraag van de sociaalwetenschappelijke bestudering van het recht. Deze vraag kent ook een meer toepassingsgerichte variant. Hoe moet het recht worden vormgegeven om de beoogde gedragseffecten te realiseren? Aan de hand van deze vraag kunnen sociaalwetenschappelijke inzichten worden gebruikt om te komen tot 'werkzame wetgeving'. Wat werkt?

Hoewel het al een hele prestatie is om te komen tot wetgeving die vanaf het moment van invoering de beoogde effecten sorteert, wil dat nog niet zeggen dat die wetgeving ook later nog werkt. Het gaat er immers niet alleen om dat het recht 'nu' de beoogde effecten heeft. Het recht moet ook voorbereid zijn op toekomstige ontwikkelingen, zeker in een tijd waarin maatschappelijke veranderingen zich sneller lijken te voltrekken dan ooit en wet- en regelgeving die maar moeilijk kunnen bijbenen, laat staan reguleren. Met het 'programma toekomstbestendige wetgeving' beoogde het vorige kabinet 'een belangrijke impuls [te geven] aan de ambitie van het kabinet om te komen tot wet- en regelgeving die voldoende ruimte biedt voor innovatie, vernieuwing en ondernemerschap, waarbij tegelijkertijd publieke belangen op een adequate manier geborgd worden'. ${ }^{1} \mathrm{De}$ wenselijkheid van toekomstbestendige wetgeving wordt ook verwoord in de strategische agenda van het ministerie van Justitie en Veiligheid:

'We investeren in toekomstbestendige wetgeving en preventieve maatregelen. (...) Voor wat betreft de wetgeving gaat het er om dat de toekomstbestendige formulering van het Burgerlijk Wetboek, de Algemene wet bestuursrecht en het Wetboek van Strafvordering er aan bijdraagt dat de verschillende rechtsgebieden (strafrecht, bestuursrecht en privaatrecht) goed op elkaar zijn afgestemd en op nieuwe ontwikkelingen kunnen worden toegepast.'

* De auteurs bedanken Carolien Klein Haarhuis, Monique Wesselink en twee anonieme referenten voor hun nuttige opmerkingen bij en discussies over eerdere versies van dit artikel.

1 Brief van de minister van Economische Zaken over innovatiebeleid van 20 juni 2015, Kamerstukken II 2014/15, 33009, 10.

2 Ministerie van Justitie en Veiligheid, Samen werken aan recht en veiligheid. Strategische agenda van het ministerie van Justitie en Veiligheid, 2017, p. 31-37. 
We richten ons op de volgende vragen:

- Wat is werkzame wetgeving, en hoe kan tot werkzame wetgeving worden gekomen?

- Wat is toekomstbestendige wetgeving, en hoe kan toekomstbestendige wetgeving worden vormgegeven?

Ons betoog is als volgt opgebouwd. In paragraaf 2 gaan we eerst in op het begrip 'beleidstheorie'. Dat doen we omdat beleid juridisch vorm krijgt in wetten en een beleidstheorie, in de kern, de aan het beleid ten grondslag liggende veronderstellingen weergeeft. Werkzame wetgeving veronderstelt een juiste beleidstheorie. Daarna gaan we, in paragraaf 3 , in op de toetsing van een beleidstheorie: hoe te bepalen of een beleidstheorie hout snijdt? In paragraaf 4 richten we ons op de vraag of voorgestelde of geïmplementeerde wetgeving helpt om een gegeven probleem op te lossen. Aansluitend kijken we, in paragraaf 5, naar toekomstbestendigheid. In paragraaf 6 presenteren we onze conclusies.

\section{Beleidstheorie}

\subsection{Begripsomschrijving}

De gedachte die aan door de overheid genomen maatregelen ten grondslag ligt, wordt wel aangeduid als 'de beleidstheorie'. Verschillende auteurs geven enigszins uiteenlopende definities van het begrip. Min of meer klassiek is de omschrijving van Hoogerwerf: 'Beleid berust op een geheel van causale en andere veronderstellingen dat men de beleidstheorie kan noemen.' ${ }^{3}$ Van Noije en Wittebrood geven een compacte begripsomschrijving: 'Een beleidstheorie is het geheel aan veronderstelde mechanismen die aan het beleid ten grondslag liggen. Deze mechanismen worden verondersteld te verklaren waarom de beleidsdoelen met de gekozen beleidsmaatregelen bereikt worden. ${ }^{4}$ Of nog compacter: 'Assumed causal mechanisms between means and ends. ${ }^{5}$

Verschillende auteurs benadrukken dat die veronderstelde verbanden lopen via de invloeden op gedrag. Vandaar dat wel wordt gesproken van 'gedragsmechanis-

3 A. Hoogerwerf, 'Beleid berust op veronderstelling: de beleidstheorie', Acta Politica 1984, p. 493.

4 L. van Noije \& K. Wittebrood, Sociale veiligheid ontsleuteld. Veronderstelde en werkelijke effecten van veiligheidsbeleid, Den Haag: SCP 2008, p. 55. Deze begripsomschrijving is nauw verwant aan de omschrijving die Hoogerwerf (1984, p. 494) in een klassiek artikel heeft gepresenteerd: 'het geheel aan veronderstellingen dat aan een beleid ten grondslag ligt'.

5 L. van Noije \& K. Wittebrood, 'Fighting Crime by Fighting Misconceptions and Blind Spots in Policy Theories. An Evidence-Based Evaluation of Interventions and Assumed Causal Mechanisms', American Journal of Evaluation (31) 2010, p. 499-516. Behalve de term 'beleidstheorie' wordt ook wel de term 'beleidslogica' gebruikt. C.M. Klein Haarhuis, 'Recht op het doel af? Over nut en noodzaak van ex-anteanalyses bij de totstandbrenging van wetgeving', RegelMaat 2010, p. 72 omschrijft beleidslogica als 'de (idealiter samenhangende) set van veronderstellingen die ten grondslag liggen aan de met een wet gemaakte keuzen'. Daarbij merkt ze op dat een adequate en onderbouwde beleidslogica geformuleerd moet worden om instrumentele doelen met behulp van wetgeving dichterbij te brengen. 
men achter overheidsinterventies'. ${ }^{6}$ Meerdere auteurs gebruiken in dit verband de term 'mechanisme'. ${ }^{7}$ Een dergelijk mechanisme weerspiegelt een causaal verband tussen de inzet van interventies en rechtsregels aan de ene kant en de realisatie van beoogde gedragseffecten aan de andere kant.

\subsection{Drie bouwstenen}

We maken onderscheid tussen drie bouwstenen van een beleidstheorie: ${ }^{8}$

1 een probleemdefinitie (welk probleem beogen beleidsmakers op te lossen of te beperken?);

2 een toeschrijving aan oorzaken (wat zien beleidsmakers als de oorzaken van de op te lossen problemen?);

3 een selectie van instrumenten (met behulp van welke instrumenten proberen beleidsmakers de problematiek op te lossen?).

Deze driedeling is nuttig omdat het helpt kritiek op beleid te duiden. Gegeven de drie onderscheiden bouwstenen kunnen de reacties betrekking hebben op problemen, oorzaken en instrumenten: 'Ze pakken de verkeerde problemen aan', 'Ze snappen niet waardoor de problemen ontstaan' of 'Ze nemen maatregelen waarvan iedereen weet dat ze niet werken.' Het is van belang te weten waarop kritiek betrekking heeft, omdat kritiek, afhankelijk van welke van de drie bouwstenen het betreft, om een andersoortige respons vraagt. ${ }^{9}$ Zo kan kritiek op wetgeving betrekking hebben op de selectie van juridische instrumenten, op de onderliggende diagnose van de oorzaken van de op te lossen problemen of op de probleemdefinitie die als aanleiding voor wetgeving werd gezien.

Naarmate een beleidstheorie 'beter' is, lukt het beter om maatschappelijke problemen op te lossen. De probleemdefinitie is beter gekozen (sluit beter aan op wat in de maatschappij als probleem wordt gezien), de diagnose is beter (de toeschrijving van problemen is in overeenstemming met hetgeen bekend is uit theoretisch en empirisch onderzoek) en de oplossing is effectiever (de gekozen instrumenten zijn instrumenten waarvan uit onderzoek bekend is dat ze werken).

\subsection{Reconstructie van een beleidstheorie}

Wie geïnteresseerd is in een beleidsterrein en verwacht in een beleidsnota een uitgewerkte beleidstheorie aan te treffen, dreigt van een koude kermis thuis te komen. Vaak ontbreekt een expliciet uitgewerkte beleidstheorie. Wie een beleidstheorie in beeld wil brengen, zal die op de een of andere manier moeten recon-

6 F.L. Leeuw, Gedragsmechanismen achter overheidsinterventies en rechtsregel (oratie Maastricht), 2008 .

7 C.M. Klein Haarhuis \& E. Niemeijer, Wet en werkelijkheid, Den Haag: WODC/Boom Juridische uitgevers 2008, p. 11.

8 Vgl. P. van Wijck \& B. Niemeijer, 'Scenario Planning Meets Frame Analysis. Using Citizens' Frames as Test Conditions for Policy Measures', Futures (77) 2016, p. 28-44.

9 Om uiteenlopende reacties op beleid te begrijpen, kan het nuttig zijn verschillende 'burgerframes' in beeld te brengen en na te gaan hoe die zich verhouden tot de beleidstheorie, oftewel het 'beleidsframe' (Van Wijck \& Niemeijer 2016). 
strueren. In Nederland is dat door Hoogerwerf op de agenda gezet. ${ }^{10}$ Dezelfde gedachte ligt ook ten grondslag aan Pawsons bekende evaluatie van 'Megan's law': 'The key is to make explicit the underlying assumptions about how an intervention is supposed to work - the "programme theory" - and then to use this theory to guide evaluation. ${ }^{11}$ Rein en Schön merken op dat de reconstructie van een beleidstheorie kan worden gebaseerd op wat beleidsmakers zeggen of schrijven dan wel op wat ze daadwerkelijk doen. In het eerste geval spreken ze van 'rethorical frames' en in het tweede geval van 'action frames'. ${ }^{12}$

Een illustratie biedt het voorstel van minister Opstelten om een wietpas in te voeren. Daarin werd het probleem gedefinieerd als straathandel en overlast in het zuiden van het land. Als oorzaak werden drugstoeristen aangemerkt. Als instrument werd de wietpas gekozen. Coffeeshops zouden moeten gaan functioneren als besloten clubs, waarin alleen personen met een (wiet)pas toegelaten zouden worden. Een pas zou alleen aan Nederlanders worden verstrekt. De beleidstheorie was dat de invoering van de wietpas zou leiden tot het vertrek van drugstoeristen, tot kleinere coffeeshops met een vaste klantenkring, en daarmee tot minder overlast. De werkelijkheid bleek weerbarstiger. De handel met drugstoeristen verplaatste zich in toenemende mate naar de straat. Nederlanders wilden zich niet laten registreren als lid bij een coffeeshop, zodat ook zij zich tot de straathandelaren richtten. De totale illegale straathandel en daarmee gepaard gaande overlast nam dus juist toe. Een ander mooi voorbeeld - veel complexer en uitgebreider ook - biedt de studie van Van Noije en Wittebrood naar het in oktober 2002 door het kabinet-Balkenende 1 gepresenteerde Veiligheidsprogramma 'Naar een veiliger samenleving. ${ }^{13}$ Van Noije en Wittebrood reconstrueren de beleidstheorie, om vervolgens te toetsen of de in de beleidstheorie veronderstelde verbanden hout snijden. Leeuw merkt op dat er in de wereld van openbaar bestuur en recht nogal wat beleidshomeopathie bestaat. De beleidstheorie achter interventies is incorrect of misschien zelfs afwezig. ${ }^{14}$

Het ontbreken van een expliciet geformuleerde beleidstheorie is geen exclusief Nederlands fenomeen.

10 Zie hierover Hoogerwerf 1984; A. Hoogerwerf, 'Reconstructing Policy Theory', Evaluation and Policy Planning (13) 1990, p. 285-291; F.L. Leeuw, 'Reconstructing Program Theories: Methods Available and Problems to Be Solved', American Journal of Evaluation (24) 2003, afl. 1, p. 5-20; Leeuw 2008; Van Noije \& Wittebrood 2008; 2010; B. Astbury \& F.L. Leeuw, 'Unpacking Black Boxes: Mechanism and Theory Building in Evaluation', American Journal of Evaluation (31) 2010, p. 363-381.

11 R. Pawson, Does Megan's Law Work? A Theory-Driven Systematic Review (Working Paper 8), ESRC UK Centre for Evidence Based Policy and Practice 2002.

12 M. Rein \& D. Schön, 'Frame-Critical Policy Analysis and Frame-Reflective Policy Practice', Knowledge and Policy 1996, afl. 9, p. 85-104.

13 Van Noije \& Wittebrood 2008. 'Naar een veiliger samenleving', Kamerstukken II 2002/03, 28684, $1-2$.

14 Leeuw 2008, p. 23. 
'The frames that shape policies are usually tacit, which means that we tend to argue from our tacit frames to our explicit policy propositions. (...) In order to reflect on the conflicting frames that underlie policy controversies, we must become aware of our frames, which is to say that we must construct them either from the texts of debates and speeches or from the decisions, laws, regulations, and routines that make up policy practice. ${ }^{15}$

De stelling dat een expliciete, getoetste, beleidstheorie vaak ontbreekt en dat dat niet helpt om tot werkzame wetgeving te komen, is overigens niet voorbehouden aan kritische wetenschappers. De per 1 januari 2018 van kracht geworden Comptabiliteitswet 2016 vraagt in artikel 3.1 in feite om een toelichting op de beleidstheorie. De minister van Financiën schreef op 13 december 2017:

'Door in de beleidsvoorbereiding heldere doelen te formuleren en inzichtelijk te maken hoe beleidsinstrumenten zullen bijdragen aan het realiseren van deze doelen, kunnen er betere uitspraken worden gedaan over de doeltreffendheid en doelmatigheid van beleid. Dit vergroot het inzicht in de wijze waarop de overheid haar middelen inzet en bevordert kwalitatief hoogwaardig en evalueerbaar beleid.' ${ }^{16}$

\section{Toetsing van de beleidstheorie: vier perspectieven}

\subsection{Ex ante versus ex post en statisch versus dynamisch}

Om te bepalen of een beleidstheorie hout snijdt, kan deze theorie op verschillende manieren worden getoetst. Daarbij kan vanuit verschillende perspectieven worden gekeken. Ten eerste maken we onderscheid tussen een ex-ante- en een expostperspectief. Daarbij gaat het vooral om de vraag wanneer toetsing plaatsvindt. Zitten we in de fase van de beleidsontwikkeling en formulering, of in de fase van het achteraf beoordelen of de zaken gelopen zijn zoals verwacht? Wordt bij de toetsing 'vooruit' of 'achteruit' gekeken? Ten tweede maken we onderscheid tussen een statisch of een dynamisch perspectief. Kenmerkend voor een statisch perspectief is dat de probleemdefinitie als gegeven wordt beschouwd, terwijl in een dynamisch perspectief de probleemdefinitie kan veranderen. Samengenomen ontstaan dan vier mogelijke toetsingsperspectieven met onderscheiden vraagstellingen (zie tabel 1).

\section{- Ex-ante-evaluatie}

Een ex-ante-evaluatie vindt plaats voorafgaand aan de invoering van beleid of de feitelijke ervaring met het beleid. Het doel ervan is het selecteren van instrumenten waarvan verwacht mag worden dat ze werken. Een typische vraag voor een $e x-$ ante-evaluatie is: valt te verwachten dat een voorgestelde aanpak gaat helpen om een vastgesteld probleem op te lossen? Die vraag heeft niet alleen betrekking op

16 Kamerbrief 'Handreiking artikel 3.1 Comptabiliteitswet 2016'. 
Tabel 1 Vier toetsingsperspectieven

\begin{tabular}{ll|ll}
\hline \multicolumn{3}{c}{ Statisch: probleemdefinitie gegeven } \\
\hline \multicolumn{5}{c}{ Ex-ante-evaluatie } & Ex-postevaluatie \\
Ex & men aanpak helpt om een vastgesteld & Heeft een gekozen aanpak geholpen & om een vastgesteld probleem op te los- Ex \\
ante: & probleem op te lossen? & post: \\
vooraf & Ex-antereflectie & Ex-postreflectie & ach- \\
& Is een voorgenomen aanpak toekomst- & Past het eerder ingezette beleid nog bij \\
bestendig? & de actuele problematiek?
\end{tabular}

\section{Dynamisch: probleemdefinitie ter discussie}

de vraag of de veronderstellingen over de oorzaken kloppen, maar ook op de vraag hoe waarschijnlijk het is dat de geselecteerde instrumenten inderdaad gaan werken op de beoogde wijze. Komen de in de beleidstheorie veronderstelde oorzaken overeen met wat bekend is uit de wetenschappelijke literatuur? En komen de in de beleidstheorie geselecteerde instrumenten overeen met op hun effectiviteit geteste instrumenten?

\section{- Ex-postevaluatie}

Het doel van een ex-postevaluatie is het controleren of geselecteerde instrumenten daadwerkelijk werken en het zo nodig bijstellen van beleid. Een ex-postevaluatie kan, per definitie, alleen plaatsvinden nadat ervaring met het beleid is opgedaan. Een typische vraag voor een ex-postevaluatie is: heeft een gekozen aanpak geholpen om een vastgesteld probleem op te lossen? Om die vraag te kunnen beantwoorden is het nuttig als er een nulmeting is, een experimentgroep en een controlegroep. Is het zo dat de groep waarop de aanpak is toegepast zich inderdaad anders gaat gedragen dan de groep waarop de aanpak niet is toegepast?

\section{- Ex-antereflectie}

Het doel van een ex-antereflectie is het ontwikkelen van toekomstbestendig beleid. Een ex-antereflectie is vooral nuttig bij de ontwikkeling van een majeur beleidsprogramma. Een typische vraag voor een ex-antereflectie is: is een voorgenomen aanpak toekomstbestendig? ${ }^{17}$ Ten opzichte van een ex-ante-evaluatie kent een ex-antereflectie een breder perspectief. In een ex-ante-evaluatie staan alleen de toeschrijving aan oorzaken en de selectie van instrumenten ter discussie. In een ex-antereflectie staat ook de probleemdefinitie ter discussie. Op langere termijn kunnen zich ontwikkelingen voordoen waardoor maatschappelijke problemen kunnen veranderen.

\section{- Ex-postreflectie}

Een belangrijk doel van een ex-postreflectie is het zo nodig herijken van de probleemdefinitie. Een typische vraag voor een ex-postreflectie is: past het eerder ingezette beleid nog bij de actuele problematiek? Ten opzichte van een ex-post- 
Tabel 2 Vier perspectieven op drie bouwstenen van een beleidstheorie

\begin{tabular}{|c|c|c|c|}
\hline & $\begin{array}{l}\text { a. Probleem- } \\
\text { definitie }\end{array}$ & $\begin{array}{l}\text { b. Inzicht in } \\
\text { oorzaken }\end{array}$ & $\begin{array}{l}\text { c. Inzicht in } \\
\text { instrumenten }\end{array}$ \\
\hline I. Ex-ante-evaluatie & $\begin{array}{l}\text { De probleemdefinitie } \\
\text { is gegeven en staat niet } \\
\text { ter discussie }\end{array}$ & $\begin{array}{l}\text { Worden problemen } \\
\text { toegeschreven aan 'de } \\
\text { juiste' oorzaken (gege- } \\
\text { ven bestaande empi- } \\
\text { risch-theoretische } \\
\text { inzichten)? }\end{array}$ & $\begin{array}{l}\text { Worden instrumenten } \\
\text { geselecteerd waarvan, } \\
\text { op grond van bestaand } \\
\text { onderzoek, bekend is } \\
\text { dat ze werken? }\end{array}$ \\
\hline 2. Ex-postevaluatie & $\begin{array}{l}\text { De probleemdefinitie } \\
\text { is gegeven en staat niet } \\
\text { ter discussie }\end{array}$ & $\begin{array}{l}\text { Wat leren we op basis } \\
\text { van het gevoerde } \\
\text { beleid? } \\
\text { Klopt de diagnose van } \\
\text { de oorzaken van het } \\
\text { probleem? }\end{array}$ & $\begin{array}{l}\text { Wat leren we op basis } \\
\text { van de resultaten van } \\
\text { het gevoerde beleid? } \\
\text { Hebben de gebruikte } \\
\text { instrumenten gewerkt? }\end{array}$ \\
\hline 3. Ex-antereflectie & $\begin{array}{l}\text { De probleemdefinitie } \\
\text { staat ter discussie: is } \\
\text { de probleemdefinitie } \\
\text { flexibel genoeg om } \\
\text { actueel te blijven? }\end{array}$ & $\begin{array}{l}\text { Is er aansluiting op } \\
\text { nieuwe inzichten in } \\
\text { oorzaken van proble- } \\
\text { men? }\end{array}$ & $\begin{array}{l}\text { Is er een feedbackme- } \\
\text { chanisme (monitorme- } \\
\text { chanisme) om de } \\
\text { instrumentkeuze aan } \\
\text { te passen aan nieuwe } \\
\text { inzichten? }\end{array}$ \\
\hline 4. Ex-postreflectie & $\begin{array}{l}\text { De probleemdefinitie } \\
\text { staat ter discussie: was } \\
\text { de gehanteerde pro- } \\
\text { bleemdefinitie goed } \\
\text { gekozen? }\end{array}$ & Was de analyse juist? & $\begin{array}{l}\text { Zijn de juiste instru- } \\
\text { menten geselecteerd, } \\
\text { of is er ruimte voor } \\
\text { verbetering? }\end{array}$ \\
\hline
\end{tabular}

evaluatie kent een ex-postreflectie een breder perspectief. De problematiek waarop het beleid was gericht, staat nu ook ter discussie. In de loop der tijd kan de problematiek, al dan niet dankzij het ingezette beleid, zijn verdwenen of van aard zijn veranderd. De vraag is daarom of de probleemdefinitie (nog) bij de tijd is.

\subsection{Vergelijking van perspectieven}

De vier perspectieven werpen een verschillend licht op de drie onderscheiden bouwstenen van een beleidstheorie (probleemdefinitie, oorzaken, instrumenten). In de vier onderscheiden perspectieven worden de drie bouwstenen op verschillende wijze (al dan niet) geproblematiseerd. Tabel 2 geeft hiervan een overzicht.

\subsection{Wanneer welk perspectief?}

Een ex-ante- of een ex-postevaluatie is nuttig om te komen tot 'wetgeving die werkt', dat wil zeggen wetgeving die helpt om een vastgestelde problematiek op te lossen, te beperken of te beheersen. Dit door een verbetering van een diagnose van de oorzaken van de problematiek of door de toepassing van effectievere instrumenten. Een ex-ante- of een ex-postreflectie is nuttig om te komen tot 'toekomstbestendige wetgeving', dat wil zeggen wetgeving die beter voorbereid is op (onzekere) toekomstige ontwikkelingen. 
Het cruciale verschil tussen de onderkant en de bovenkant van de matrix in tabel 1 is dat aan de onderkant ook de probleemdefinitie ter discussie wordt gesteld. Een belangrijke voorwaarde daarvoor is dat hiervoor binnen een organisatie de ruimte bestaat. ${ }^{18}$ In het statisch perspectief is de probleemdefinitie gegeven. Bij een juiste toeschrijving aan oorzaken en een juiste selectie van instrumenten lukt het om het probleem op te lossen of te reduceren. In het dynamisch perspectief kan de probleemdefinitie veranderen, vanwege een verandering van de feitelijke situatie of een verandering in de perceptie. Dat leidt tot een extra vraag: is de probleemdefinitie actueel en flexibel genoeg om aan te passen aan veranderende omstandigheden?

\section{Werkzame wetgeving}

\subsection{Wat is werkzame wetgeving?}

In het voorgaande hebben we ons gericht op de toetsing van beleidstheorieën. Wetgeving en beleidstheorieën hangen nauw samen. Wetten zijn zowel beleidsinstrument als zodanig als de juridische verschijningsvorm van beleid. Met wetten en beleid wordt getracht gedrag van maatschappelijke actoren in een gewenste richting te sturen. ${ }^{19}$ Werkzame wetgeving is wetgeving waarmee het lukt om gedrag in een 'gewenste richting' te sturen. Het idee van 'werkzame wetgeving' is passend indien wordt gekeken vanuit een statisch perspectief, waarin de probleemdefinitie niet ter discussie staat.

\subsection{Hoe werkzame wetgeving te ontwikkelen?}

Het ontwikkelen van werkzame wetgeving vergt een beleidstheorie. Wat is uit betrouwbare bron ('evidence based') bekend over het probleem in kwestie, de oorzaken ervan en over de effectiviteit van interventies? Het gaat dan om het uitvoeren van een ex-ante-evaluatie: het vooraf toetsen van de plausibiliteit van de beleidstheorie.

Men kan ook achteraf kijken of wetgeving heeft gebracht wat ervan verwacht werd. Dan is sprake van een ex-postevaluatie. Bij ex-postevaluaties is onderscheid te maken tussen doelbereikingsevaluaties en effectevaluaties. In het eerste geval wordt volstaan met het meten van de mate van doelbereiking. Daarbij ligt een ('post hoc ergo propter hoc'-)denkfout op de loer: na de invoering of verandering zien we een verbetering optreden, dus de wetgeving heeft tot de beoogde verbetering geleid. Dat hoeft uiteraard niet zo te zijn. Er kunnen tal van andere oorzaken van de verbetering bestaan. Daarom is het problematisch dat de meeste wetsevaluaties niet verder komen dan een doelbereikingsevaluatie. ${ }^{20}$ 


\subsection{Werkzame wetgeving en het IAK}

Er bestaan meerdere initiatieven om te komen tot betere wetgeving. Een van die initiatieven is het Integraal Afwegingskader voor beleid en regelgeving (IAK). De vraag dringt zich op hoe bovenstaande noties om te komen tot werkzame wetgeving zich verhouden tot het IAK.

Tabel 3 geeft een samenvattend overzicht van het IAK. ${ }^{21}$

\section{Tabel 3 Samenvattend overzicht van het Integraal Afwegingskader voor beleid en regelgeving}

\begin{tabular}{|c|c|c|c|c|}
\hline Fase I Probleemanalyse & \multicolumn{2}{|c|}{ Fase 2 Instrumentkeuze } & \multicolumn{2}{|c|}{$\begin{array}{l}\text { Fase } 3 \text { Gevolgen- } \\
\text { beoordeling }\end{array}$} \\
\hline $\begin{array}{ll}\text { I Wat is de aanleiding? } \\
2 \text { Wie zijn betrokken? } \\
3 \text { Wat is het probleem? } \\
4 \text { Wat is het doel? } \\
5 \text { Wat rechtvaardigt over- } \\
\text { heidsinterventie? }\end{array}$ & 6 & $\begin{array}{l}\text { Wat is het beste instru- } \\
\text { ment? } \\
-\quad \text { Instrumenten } \\
-\quad \text { Rechtmatigheid, uit- } \\
\text { voerbaarheid en doel- } \\
\quad \text { matigheid } \\
-\quad \text { Invoeren van beleid }\end{array}$ & 7 & $\begin{array}{l}\text { Wat zijn de gevolgen? } \\
-\quad \text { Evaluatie en } \\
\text { monitoring }\end{array}$ \\
\hline Breng het probleem in kaart & & $\begin{array}{l}\text { aal welk(e) instrument(en) } \\
\text { zet moet(en) worden om } \\
\text { probleem op te lossen }\end{array}$ & & $\begin{array}{l}\text { aal wat de gevolgen zijn } \\
\text { de voorgestelde oplos- } \\
\text { en geef aan hoe dit } \\
\text { valueerd gaat worden }\end{array}$ \\
\hline
\end{tabular}

Wanneer we de IAK-vragen naast de drie bouwstenen van een beleidstheorie leggen, dan ontstaat het volgende beeld.

De eerste bouwsteen van een beleidstheorie betreft de probleemdefinitie: welk probleem beogen beleidsmakers op te lossen of te beperken? Dit behoort duidelijk tot fase 1 van het IAK. De beantwoording van de IAK-vragen uit fase 1 leidt in beginsel tot de probleemdefinitie.

De tweede bouwsteen van een beleidstheorie betreft de toeschrijving aan oorzaken: wat zien beleidsmakers als de oorzaken van de op te lossen problemen? Dit is een cruciale stap, omdat de oplossing van problemen vraagt om instrumenten die aangrijpen bij de oorzaken van de problemen. De vraag naar oorzaken zien we niet expliciet terug in de IAK-vragen. Door niet expliciet bij de oorzaken stil te staan dreigt het risico van symptoombestrijding. ${ }^{22}$

De derde bouwsteen van een beleidstheorie betreft de selectie van instrumenten: met behulp van welke instrumenten proberen beleidsmakers de problematiek op te lossen? De selectie van instrumenten behoort tot de tweede fase uit het IAK. Welke effecten kunnen van verschillende instrumenten worden verwacht, en welk instrument of welke instrumenten kunnen daarom het beste worden ingezet? Hier zien we, tenminste impliciet, een ex-ante-evaluatie.

Fase drie van het IAK gaat niet zozeer over een bouwsteen van een beleidstheorie, als wel om de evaluatie van een beleidstheorie: valt te verwachten dat een geselec-

21 Dit overzicht is ontleend aan de AIK-waaier: www.naarhetiak.nl.

22 Symptoombestrijding is natuurlijk niet zinloos. Het kan bijvoorbeeld bijdragen aan de beheersing van het probleem. 
teerd instrument gaat werken, en hoe ga je beoordelen of dat ook echt zo is? De IAK-vragen, vooral vraag 6 en 7, bieden duidelijk aanknopingspunten voor exante- en ex-postevaluaties.

\section{Toekomstbestendige wetgeving}

\subsection{Wat is toekomstbestendige wetgeving?}

Toekomstbestendige wetgeving is wetgeving die voorbereid is op maatschappelijke veranderingen. Indien zich veranderingen voordoen, is er geen noodzaak tot aanpassing van de wet, omdat de wetgever al bij de vormgeving van wetgeving op veranderingen heeft geanticipeerd. Het idee van 'toekomstbestendige wetgeving' is passend indien wordt gekeken vanuit een dynamisch perspectief, waarin problemen veranderlijk zijn.

Toekomstbestendige wetgeving kan verschillende vormen aannemen. Enerzijds kan toekomstbestendige wetgeving robuuste wetgeving zijn. Wetgeving is dan zodanig vormgegeven, dat redelijkerwijs verwacht kan worden dat deze in de voorzienbare toekomst adequaat is, want bestand tegen veranderingen. Anderzijds kan toekomstbestendige wetgeving juist flexibele wetgeving zijn. De voor de wetgeving relevante context is zo veranderlijk, dat er aanleiding is om flexibiliteit op voorhand in te bouwen. ${ }^{23}$

De behoefte aan toekomstbestendige wetgeving bestaat vooral op gebieden waarop zich maatschappelijke ontwikkelingen voordoen die niet goed voorspelbaar zijn. Zo geldt bijvoorbeeld voor productie die met milieuvervuiling gepaard gaat, dat de milieuproblematiek afhangt van - onder meer - de omvang van de productie en van de gebruikte techniek. Wanneer specifiek wordt bepaald welke techniek mag worden gebruikt, is een dergelijke bepaling snel achterhaald. Een open norm kan hier beter werken. Een ander, enigszins omstreden, voorbeeld betreft de Algemene Ouderdomswet (AOW). Door demografische ontwikkelingen komt de betaalbaarheid van de AOW in het gedrang. En dat kan aanleiding geven tot aanpassing van de AOW-gerechtigde leeftijd. Omdat de demografische ontwikkeling niet precies voorspelbaar is, zou een automatische koppeling van die leeftijd aan geconstateerde demografische ontwikkelingen soelaas kunnen bieden. Meer specifiek: artikel 7a AOW bevat een formule waarin de door het CBS geraamde 'macro gemiddelde resterende levensverwachting op 65-jarige leeftijd in het kalenderjaar van verhoging' bepalend is voor de periode waarmee de pensioengerechtigde leeftijd wordt verhoogd.

De vraag die zich dan opdringt, is of toekomstbestendige wetgeving wenselijk is, en zo ja, hoe dat dan vorm te geven?

23 Met Gert Jan Veerman kunnen we ons afvragen of het logisch is dat een zoektocht naar bestendigheid tot de conclusie leidt dat flexibiliteit nodig is (G.J. Veerman, 'Toekomstbestendige wetgeving: duurzaam? wendbaar? duurzaam wendbaar?', RegelMaat 2016, p. 82-101). Flexibiliteit is bestendigheid heeft iets van orwelliaans dubbel denken: 'war is peace, freedom is slavery, ignorance is strength'. Veerman (2016, p. 100) schetst 'duurzame wendbaarheid' als een oxymoron. Het is overigens de vraag of het hier gaat om een oxymoron dan wel een paradox. 


\subsection{Is toekomstbestendige wetgeving wenselijk?}

De wenselijkheid van het zodanig vormgeven van wetgeving dat deze toekomstbestendig is, lijkt evident. Het is in elk geval onwenselijk indien al snel na invoering de noodzaak tot aanpassing aan het licht komt. Dat wetgeving innovatie in de weg zou kunnen zitten, is aanleiding geweest voor het programma toekomstbestendige wetgeving. Het programma beoogde om in wetgeving en het wetgevingsproces structureel aandacht te krijgen voor vernieuwing, innovatie en ondernemerschap, steeds in relatie tot alle publieke waarden die in het geding zijn. Het programma heeft onder meer geleid tot uitbreiding van het IAK met informatie over doelregulering, experimenteerruimte en het 'right to challenge'. Ook is in de bedrijfseffectentoets een vraag opgenomen die aandacht van beleidsmakers vraagt voor het eventuele effect van de voorgenomen regelgeving op het innovatiepotentieel van bedrijven.

Toch zijn hier kanttekeningen bij te plaatsen. Zo staat flexibiliteit op gespannen voet met rechtszekerheid. Wie wetgeving vooral ziet als regels die rechtszekerheid bieden, zal reserves hebben bij de gedachte dat flexibiliteit in wetgeving ingebouwd moet worden. Het is aan rechters om te beslissen hoe wetten onder wijzigende omstandigheden geïnterpreteerd moeten worden. En als een nieuwe interpretatie uitgekristalliseerd is, kunnen wetten zo nodig worden aangepast. Wat daartegen in te brengen is, is dat wetten dan niet alleen altijd achter de feiten zullen aanlopen, maar ook nieuwe ontwikkelingen in de weg kunnen zitten.

Zo bezien bestaat er een afruil tussen flexibiliteit en rechtszekerheid. Het verabsoluteren van de ene kant gaat ten koste van de andere kant. De kritiek van de Raad van State op het programma toekomstbestendige wetgeving past in deze denklijn. ${ }^{24}$ Met het 'programma toekomstbestendige wetgeving' beoogde het vorige kabinet 'een belangrijke impuls [te geven] aan de ambitie van het kabinet om te komen tot wet- en regelgeving die voldoende ruimte biedt voor innovatie, vernieuwing en ondernemerschap, waarbij tegelijkertijd publieke belangen op een adequate manier geborgd worden'. De Raad van State reageerde kritisch. In het Jaarverslag 2015 wordt onder meer opgemerkt dat tijdige aanpassing van wet- en regelgeving om nieuwe maatschappelijke ontwikkelingen mogelijk te maken weliswaar van wezenlijk belang is, maar dat dat niet moet doorslaan. Als de nadruk eenzijdig komt te liggen op doelmatigheid op zo kort mogelijke termijn, dan wordt ingeleverd op de waarden van de rechtsstaat. Als rechtswaarborgen en rechtseenheid worden geofferd aan snelheid, resultaat en draagvlak dreigt een krachtmeting tussen rechter, bestuur en wetgever. ${ }^{25}$ In het Jaarverslag 2016 wordt gewaarschuwd dat snelle verandering kan leiden tot verlies aan structuur en samenhang, en daarmee tot onzekerheid en afname van vertrouwen. Wend-

24 Zie over dit programma: brief van 20 juni 2015 van de minister van Economische Zaken over innovatiebeleid, Kamerstukken II 2014/15, 33009, 10. En de brief van 18 december 2015, Kamerstukken II 2015/16, 33009, 12. En de Afsluitende brief programma toekomstbestendige wetgeving van 26 juni 2017 van de ministers van Economische Zaken (EZ) en Veiligheid en Justitie (VenJ). De, hierna besproken, kritiek van de Raad van State staat in de jaarverslagen van de Raad over 2015 en 2016.

25 Zie hierover onder meer S. Zouridis, W. Wierenga \& B. Niemeijer, 'De rechtsstaat: van sluitpost naar "Leitmotiv", NJB 2016, afl. 19, p. 1337-1342. 
bare wetgeving is, aldus de Raad, ook altijd kenbare wetgeving die rechtszekerheid biedt.

De gedachte aan de wenselijkheid van toekomstbestendige wetgeving is overigens niet nieuw. Het Europees Economisch en Sociaal Comité pleit in enkele adviezen voor toekomstbestendige regelgeving. In 2009 bracht het Comité een advies uit over de proactieve benadering van het recht. ${ }^{26}$ In de kern bepleit het Comité om bij de vormgeving van regulering minder te kijken naar het verleden en meer naar hoe het recht in de toekomst gebruikt gaat worden. Onderstaande citaten illustreren dit:

'In juridische kringen is veel te lang de nadruk op het verleden gelegd.' (art 1.3)

'Het Comité pleit voor een mentaliteitsverandering. De tijd is gekomen om de eeuwenoude reactieve benadering van het recht te vervangen door een proactieve benadering. Het is tijd voor een andere benadering; tijd om vooruit te kijken in plaats van achteruit, om zich te concentreren op hoe het recht in het dagelijks leven wordt gebruikt en functioneert en hoe het wordt ontvangen in de gemeenschap waarop de regels zijn gericht.' (art 1.4)

In 2016 publiceerde het Comité een advies over toekomstbestendige regelgeving. ${ }^{27}$ Uit dit advies spreekt de wens tot een regulering die toekomstgericht is en die zich aanpast. De volgende citaten illustreren dit:

'Europese regelgeving is toekomstbestendig als zij proactief en toekomstgericht is; het EESC is voorstander van regelgeving die zich aanpast.' (art. 1.7)

'Het EESC stelt vast dat niet alleen de inhoud van de regelgeving, maar ook het regelgevingsproces zelf toekomstbestendig moet zijn om aan de behoeften van het bedrijfsleven en de burgers te voldoen.' (art. 1.10)

Behalve deze betrekkelijk algemene adviezen bestaan er ook meer specifieke pleidooien. Van recente datum is Anna Gerbrandy's pleidooi voor een toekomstbestendig mededingingsrecht:

'Dat is mededingingsrecht dat relevantie behoudt omdat het zich verhoudt tot maatschappelijke ontwikkelingen, inclusief ontwikkelingen die we in de toekomst verwachten. Hieraan ligt ten grondslag dat het recht niet op zichzelf staat, maar zich dient te verhouden tot zijn maatschappelijke context: recht dient responsief te zijn.'28

26 Advies van het Europees Economisch en Sociaal Comité, 'De proactieve benadering van het recht: een stap voorwaarts naar betere regelgeving op EU-niveau' (2009/C 175/05), Publicatieblad van de Europese Unie 28 juli 2009, C 175/26.

27 Advies van het Europees Economisch en Sociaal Comité, 'Toekomstbestendige regelgeving', SC/ 045, 21 september 2016.

28 A. Gerbrandy, 'Toekomstbestendig mededingingsrecht', Markt en Mededinging 2016, p. 102. 
Binnen het justitiedomein bestaan meerdere voorbeelden van projecten waarbij systematisch is nagedacht over de vraag hoe zo goed mogelijk geanticipeerd kan worden op toekomstige ontwikkelingen. ${ }^{29}$

\subsection{Hoe toekomstbestendige wetgeving te ontwikkelen?}

Kenmerkend voor toekomstbestendige wetgeving is dat het wetgeving is die op maatschappelijke veranderingen is voorbereid. Het ontwikkelen van toekomstbestendige wetgeving vergt daarom het in beeld brengen van de relevante veranderingen. Hoe toekomstige ontwikkelingen eruitzien is echter niet met zekerheid te zeggen. Hoe langer de tijdshorizon, des te groter de onzekerheid zal zijn. Bij het ontwikkelen van toekomstbestendigheid is het zaak expliciet stil te staan bij onzekerheid die er bestaat over toekomstige ontwikkelingen. Het gaat dus juist niet om het zo goed mogelijk voorspellen van toekomstige ontwikkelingen. Sommigen menen zelfs dat voorspellen in de ban gedaan moet worden. ${ }^{30}$

Een typische startvraag voor het ontwikkelen van toekomstbestendige wetgeving is: met welke ontwikkelingen kunnen we de komende $\mathrm{x}$ jaar te maken krijgen? Deze vraag bevat een aantal kenmerkende elementen. 'Kunnen' verwijst naar onzekerheid. Juist omdat de toekomst onzeker is, staat hier expliciet niet 'zullen'. 'Te maken krijgen' verwijst naar van buiten komende, niet of nauwelijks te beïnvloeden ontwikkelingen. Het gaat om ontwikkelingen die zich kunnen voordoen en waar de wetgever zich op de een of andere wijze toe moet verhouden. Verder verwijst 'we' naar degene die zich wil voorbereiden op ontwikkelingen waar hij op langere termijn mee te maken kan krijgen, bijvoorbeeld een bepaald ministerie. De vraag hoever in de tijd vooruitgekeken moet worden, is afhankelijk van de zogenaamde 'lead time'. Hoeveel tijd kost de ontwikkeling en implementatie van wetgeving op het relevante domein naar verwachting?

29 Zie E.J. Arkenbout, F. van Dijk \& P.W. van Wijck, Auteursrecht in de informatiemaatschappij. Bouwstenen voor een justitiestrategie, Den Haag: Ministerie van Justitie 2001, over auteursrecht, N. Janssen, P. de Ruijter \& M. Gramberger, Scenario's en dynamisch beleid. Onderzoek naar de scenariomethode als instrument voor ex ante toetsing van wet- en regelgeving en ontwikkeling van dynamisch beleid. Casus: Artikel 20 van de nieuwe Drank- en Horecawet, Den Haag: WODC 2002, over de Drank- en Horecawet, Expertisecentrum Rechtshandhaving, Laveren tussen Scylla en Charibdis. Over de toekomst van handhaving, Den Haag: Ministerie van Justitie 2005, over rechtshandhaving, Directie Algemene Justitiële Strategie, Justitie over morgen: scenario's en strategieën voor 2015, Den Haag: Ministerie van Justitie 2007, over de beleidsterreinen van Justitie, en S. Zouridis, S. Muller, L. Kistemaker \& M. Frishman, 'The Global Legal Environment and Its Future: Four Scenarios', Tilburg Law Review (17) 2012, p. 332-345, over de globale rechtsorde.

30 M.B.A. van Asselt, A. Faas, F. van der Molen \& S.A. Veenman (red.), Uit zicht: toekomstverkennen met beleid (WRR-verkenning 24), Den Haag: Wetenschappelijke Raad voor het Regeringsbeleid 2010, p. 54. 
De ontwikkeling van toekomstbestendige wetgeving vergt een aantal stappen. Verschillende auteurs schetsen enigszins uiteenlopende stappenplannen. Maar grosso modo komt het op het volgende neer. ${ }^{31}$

Een eerste stap is het in beeld brengen van ontwikkelingen die zich op langere termijn in de omgeving kunnen voordoen. De mate waarin die ontwikkelingen impact hebben op de relevante problematiek loopt uiteen. Bovendien is de mate van onzekerheid niet voor alle ontwikkelingen gelijk. De belangrijkste ontwikkelingen zijn de ontwikkelingen die hoog scoren op zowel impact als onzekerheid.

De tweede stap bestaat dan uit het, op basis van de belangrijkste onzekerheden, ontwikkelen van verschillende plausibele toekomstbeelden, oftewel toekomstscenario's. ${ }^{32}$ Scenario's moeten niet alleen plausibel, maar ook relevant en verrassend zijn. Scenario's zijn relevant indien ze leiden tot uiteenlopende probleemdefinities (spanning tussen feitelijke en gewenste situatie) en/of uiteenlopende reacties vragen. Ze zijn verrassend indien ze tot inzichten leiden die afwijken van verwachtingen op basis van het eenvoudigweg doortrekken van trends.

In de derde stap staat een 'what if-vraag' centraal: stel dat ontwikkelingen zich langs de in een scenario geschetste lijn voltrekken, wat zou dan passende wetgeving zijn?

De vierde stap staat bekend als de windtunneltest. De verschillende scenario's fungeren als 'testcondities in een windtunnel'. ${ }^{33}$ Deze procedure maakt het mogelijk om na te gaan of voorgestelde wetgeving in alle plausibele toekomsten (de testcondities in de windtunnel) werkt. Wanneer dat niet zo is, komt de vraag naar voren of het inbouwen van flexibiliteit soelaas biedt. Uiteindelijk is dan een expliciete keuze nodig over de vraag of, en zo ja hoe, op onzekere ontwikkelingen geanticipeerd moet worden. Voor het maken van deze keuze kunnen verschillende strategieën worden gevolgd. Die variëren van een robuuste strategie (zet alleen die opties in die in alle scenario's werken) en een flexibele strategie (zorg dat verschillende opties gereedstaan die kunnen worden geactiveerd zodra duidelijk is welk scenario zich ontvouwt) tot wedden op één paard (gok erop dat een van de mogelijke scenario's zich ontvouwt). ${ }^{34}$

31 Zie bijv. Scearce \& Fulton 2004 of P. de Ruijter, S. Stolk \& H. Alkema, Klaar om te wenden, Schiedam: Scriptum 2011. P. Schwartz, The Art of the Long View. Planning for the Future in an Uncertain World, New York: John Wiley 1996, p. 241-248, beschrijft acht stappen: (1) identify focal issue or decision; (2) key forces in the local environment; (3) driving forces; (4) rank by importance and uncertainty; (5) selecting scenario logics; (6) fleshing out the scenarios; (7) implications; (8) selection of leading indicators and signposts. Janssen e.a. (2002) beschrijven ook acht stappen: (1) scenarioproject voorbereiden; (2) externe omgeving verkennen; (3) scenario's ontwikkelen; (4) implicaties van de scenario's bepalen; (5) wetgeving ex ante toetsen; (6) beleidsopties genereren; (7) beleidsopties ex ante evalueren; (8) toekomstvast dynamisch beleid ontwikkelen.

32 Hoewel het vrij gebruikelijk is om aan de hand van twee (onafhankelijke) kernonzekerheden vier scenario's te ontwikkelen, is dat zeker niet de enige mogelijkheid.

33 Zie bijv. K. van der Heijden, Scenarios: The Art of Strategic Conversation, Chichester: Wiley 1996, p. 234, C.H. Perrottet, 'Testing Your Strategies in Scenarios', in: L. Fahey \& R.M. Randall (red.), Learning from the Future, New York: Wiley 1998, p. 122-139 of De Ruijter e.a. 2011, p. 134.

34 Zie bijv. K. van der Heijden, Scenarios, Strategies and the Strategy Process, Breukelen: Nijenrode University Press 1997. 
De laatste stap betreft de vraag hoe met de uitkomst van de windtunneltest om te gaan. Een windtunneltest kan tot de conclusie leiden dat voorgestelde wetgeving in alle scenario's werkt. De voorgestelde wetgeving is zo bezien 'robuust'. Gegeven plausibele toekomstige ontwikkelingen lijkt niet te verwachten dat aanpassing van wetgeving nodig zal zijn. Maar het kan ook zo zijn dat de verschillende toekomstbeelden tot dusdanig verschillende problematiek leiden, dat flexibiliteit nodig is. De gedachte is dan dat normen aanpasbaar moeten zijn, om passend te kunnen blijven in een sterk veranderlijke omgeving. Vandaar dat het belangrijk is om te monitoren hoe omgevingsontwikkelingen zich ontvouwen. ${ }^{35}$

\section{- Voorbeeld 1: de Drank- en Horecawet}

Janssen e.a. gaan uitgebreid in op het gebruik van scenario's voor de ex-antetoetsing van de Drank- en Horecawet. ${ }^{36}$ De auteurs onderscheiden twee kernonzekerheden: de eerste betreft de vraag of de populariteit van alcohol hoog of laag is, en de tweede gaat over de vraag of volwassenen mee- of tegenwerken. In scenario 1 , genaamd 'De maatschappelijke leugen', is de populariteit van alcohol onder jongeren en ouderen hoog. De overheid wordt aangezet tot symbool- en incidentpolitiek. In scenario 2, 'Drooglegging', ontstaat draagvlak voor zero tolerance en hard optreden. Gedogen is voorbij. De keerzijde hiervan is dat het gebruik van alcohol stiekem gebeurt en allerlei ondergrondse activiteiten en criminaliteit aantrekt. In scenario 3, 'Spa en XTC', is Nederland verdeeld. Sommige groepen jongeren drinken principieel niet, andere vinden alcohol maar saai in vergelijking tot nieuwe drugs. Ouderen kan het allemaal niet veel schelen. In scenario 4, 'Latin', zetten incidenten de omgang met alcohol hoog op de agenda. Ouderen en jongeren trekken samen op en leren elkaar goed met alcohol om te gaan. De verschillende scenario's fungeren als testcondities om na te gaan hoe maatregelen onder verschillende omstandigheden werken. Zo werkt, bijvoorbeeld, het bevorderen van leeftijdscontrole goed in scenario 1 en 2 , maar is het juist contraproductief in scenario 3 en 4 . Toegangscontrole werkt goed in scenario 2 en 3 , terwijl het contraproductief is in scenario 1 en 4 .

\section{- Voorbeeld 2: beprijzing weggebruik}

Een recent voorbeeld illustreert dat het ook mogelijk is om bestaande scenario's te gebruiken bij het ontwerpen van regelgeving. ${ }^{37}$ Het Centraal Planbureau en het Planbureau voor de Leefomgeving hebben alternatieve vormgeving van beprijzing van wegverkeer getoetst aan verschillende scenario's die in het kader van 'Welvaart en leefomgeving' (WLO) zijn ontwikkeld. ${ }^{38}$ Omdat de economische ontwikkeling, en daarmee het weggebruik, in de verschillende scenario's sterk uiteen-

36 Janssen e.a. 2002.

37 CPB \& PBL, Maatschappelijke kosten en baten prijsbeleid personenauto's, Centraal Planbureau en Planbureau voor de Leefomgeving 2015.

38 De WLO-scenario's staan beschreven in: CPB, MNP \& RPB, Welvaart en leefomgeving. Een scenariostudie voor Nederland in 2040, Centraal Planbureau, Milieu- en Natuurplanbureau en Ruimtelijk Planbureau 2006. 
loopt, ligt het in de rede te toetsen hoe alternatieve vormen van beprijzing uitwerken in die verschillende scenario's.

\subsection{Instrumenten ter vergroting van flexibiliteit}

Zoals hiervoor beschreven gaat het bij het ontwikkelen van toekomstbestendige wetgeving om het zoeken naar oplossingen die maken dat wetgeving niet ad hoc hoeft te worden aangepast indien de relevante problematiek verandert onder invloed van ontwikkelingen van buiten af. De gedachte is dat dat kan door flexibiliteit op voorhand in te bouwen. ${ }^{39}$ Daarmee komen we uit bij de vraag welke instrumenten geschikt zijn om flexibiliteit te vergroten. Hieronder bespreken we kort enkele instrumenten waarmee dat kan. ${ }^{40}$

\section{- Formuleer geen middel- maar doelvoorschriften}

Vanuit een statisch perspectief (met een gegeven probleemdefinitie, kennis van de oorzaken en kennis van de effectiviteit) kan het effectief zijn indien de wetgever voorschrijft hoe iemand moet handelen. Vanuit een dynamisch perspectief kan het beter zijn om voor te schrijven wat iemand moet bereiken. Hoe iemand dat bereikt, mag hij zelf bepalen. (Een middelvoorschrift gaat om het 'hoe' en een doelvoorschrift om het 'wat'.) Een doelvoorschrift is flexibeler. Als er nieuwe relevante informatie komt, kan iemand zijn gedrag aanpassen indien hij daarmee eenvoudiger het gestelde doel kan bereiken. Een voorbeeld van een middelvoorschrift zou zijn dat een auto een bepaald type katalysator moet hebben, een doelvoorschrift zou zijn dat een auto niet meer dan $\mathrm{x}$ gram stikstofoxide per kilometer mag uitstoten.

\section{- Delegeer regelgevende bevoegdheden}

Het aanpassen van een wettelijke norm kost tijd. Dat gaat gemakkelijker als de norm door een andere instantie aangepast kan worden. Van een nog iets andere orde: de AOW-leeftijd is geen wettelijk vastgelegde leeftijd, maar de uitkomst van demografische ramingen die periodiek worden geactualiseerd. De spanning tussen flexibiliteit en rechtszekerheid is hier goed te zien.

\section{- Formuleer open normen}

Een keuze voor open normen maakt dat de rechter invulling kan geven aan wat op een gegeven moment redelijkerwijs verwacht mag worden. Daarmee vindt in feite - op basis van individuele gevallen - een voortdurende actualisatie plaats.

39 De gedachte dat stabiliteit flexibiliteit vereist, komt vaker voor in strategische verkenningen. Een van de strategische opgaven uit Justitie over morgen, een strategische verkenning voor het ministerie van Justitie, luidt: 'Wees flexibel om stabiel te kunnen zijn' (Directie Algemene Justitiële Strategie 2007, p. 130).

40 Deze ontlenen we aan de, in voetnoot 24 genoemde, Afsluitende brief programma toekomstbestendige wetgeving van 26 juni 2017 van de ministers van EZ en VenJ, G.J. Veerman, Evaluatie van wetgeving? Bouwstenen voor beslissingen (Digitale publicatiereeks Recht en Overheid), 2014, de jaarverslagen van de Raad van State voor 2015 en 2016 en het, in voetnoot 27 genoemde, Advies van het Europees Economisch en Sociaal Comité over toekomstbestendige regelgeving uit 2016. 
Een voorbeeld is het as low as reasonably achievable (ALARA)-beginsel uit het milieurecht.

- Vermijd onnodige details en formuleer techniekonafhankelijk

Op een bepaald moment kan het voorschrijven van het gebruik van een bepaalde technologie heel effectief zijn. Maar in de loop der tijd kunnen nieuwe, mogelijk betere, technieken beschikbaar komen. Door onnodige detaillering te vermijden is het minder vaak nodig om nieuwe regels te maken voor nieuwe situaties.

\section{- Right to challenge}

Dit is een nieuw instrument. De gedachte is dat de wetgever een doelbepaling formuleert en ook aangeeft hoe daaraan voldaan moet worden. Burgers en bedrijven krijgen echter de wettelijke mogelijkheid om het doel van een wettelijke regeling op hun eigen manier te realiseren.

\section{- Creëer experimenteerbepalingen}

Experimenteren kan helpen om uit te proberen en te leren wat de beste aanpak is. Vaak bestaat daarvoor meer ruimte in de bestaande regelgeving dan van tevoren wordt gedacht. Ook wordt bepleit wetgeving te maken die experimenteren mogelijk maakt. ${ }^{41}$

\section{- Tijdelijke wetgeving ('sunset clauses')}

De gelding van tijdelijke wetgeving is van beperkte duur. Dat dwingt de wetgever om na te denken of er aanleiding is de bestaande wetgeving niet te verlengen, ongewijzigd te verlengen of gewijzigd te verlengen. Op deze manier krijgt de wetgever een prikkel om wetgeving bij de tijd te houden.

\subsection{Toekomstbestendige wetgeving en het IAK}

We hebben toekomstbestendige wetgeving omschreven als wetgeving die is voorbereid op maatschappelijke veranderingen. Cruciaal daarbij is dat onzekerheid over toekomstige ontwikkelingen wordt geëxpliciteerd. Alleen dan kan er immers expliciet worden afgewogen of er aanleiding is om daarvoor voorzieningen te treffen. Dat roept de vraag op of er in het wetgevingsproces iets is ingebouwd dat aanzet tot het expliciteren van onzekerheid.

Eerder hebben we gezien dat het IAK een aantal vragen bevat die helpen om te komen tot werkzame wetgeving. Het IAK biedt echter weinig aanknopingspunten om te komen tot toekomstbestendige wetgeving. Zoals vermeld in paragraaf 5.2 vraagt de bedrijfseffectentoets wel aandacht voor de mogelijke impact van wetgeving op innovatie. Maar dat geeft nog geen antwoord op de vraag of de wetgeving is voorbereid op ontwikkelingen die zich in de omgeving kunnen voordoen. Vraag 3 luidt 'Wat is het probleem?', niet 'Met welke problemen kunnen we de komende $\mathrm{x}$ jaar te maken krijgen?’ De gedachte dat toekomstige exogene ont- 
wikkelingen tot een verandering van de problematiek kunnen leiden, komt daarom niet expliciet in beeld.

\section{Conclusie}

Werkzame wetgeving is wetgeving die leidt tot een oplossing of beperking van een bepaalde problematiek. Om te komen tot werkzame wetgeving is een beleidstheorie nodig. De theorie geeft inzicht in de problematiek, de oorzaken van die problematiek en in de instrumenten die helpen om de problematiek op te lossen of te beperken. In de praktijk blijken expliciet geformuleerde beleidstheorieën schaars. En dat geldt ook voor de ex-ante- of ex-posttoetsing ervan. Daardoor is er relatief weinig inzicht in de vraag of wetgeving de beoogde effecten heeft. De IAK-vragen zijn zeker nuttig, omdat ze min of meer dwingen een beleidstheorie op te stellen. Extra aandacht voor het expliciteren van de veronderstelde oorzaken van de problematiek lijkt echter niet overbodig. ${ }^{42}$

Het concept 'werkzame wetgeving' past bij een statisch perspectief, waarbij de problematiek als gegeven wordt beschouwd. Het concept 'toekomstbestendige wetgeving' past juist bij een dynamisch perspectief, waarbij er rekening mee wordt gehouden dat problematiek onder invloed van onzekere exogene ontwikkelingen kan veranderen. Onder 'toekomstbestendige wetgeving' verstaan we wetgeving die is voorbereid op maatschappelijke veranderingen. Dat betekent dat onzekerheid over toekomstige ontwikkelingen moet worden geëxpliciteerd. In de praktijk vergt dat systematisch nadenken over plausibele toekomstbeelden en de bijbehorende problematiek en het eventueel inbouwen van flexibiliteit om met onzekerheid om te gaan.

Een belangrijke voorwaarde om te komen tot werkzame en toekomstbestendige wetgeving is dat er bij de ontwikkeling van wetgeving ruimte bestaat om de beleidstheorie, inclusief de probleemdefinitie, ter discussie te stellen. Ter voorkoming van 'homeopathische wetgeving' is een beleidstheorie nodig die verklaart hoe de voorgestelde wetgeving bijdraagt aan het oplossen van een omschreven probleem. Sluiten voorgenomen maatregelen aan bij wat bekend is over de veronderstelde gedragsmechanismen? Zonder expliciete beleidstheorie is het maar zeer de vraag of voorgenomen maatregelen een verandering ten goede zullen bewerkstelligen. Men kan zich dan afvragen of het nemen van die maatregelen nu wel verstandig is. Bij afwezigheid van een expliciete beleidstheorie zou 'niets doen'

42 Indien een ex-ante- of ex-posttoetsing tot de conclusie leidt dat een interventie inderdaad werkt, dan betekent dat nog niet dat de maatschappelijke baten de maatschappelijke kosten overtreffen. Om na te gaan of dat zo is, zou een 'maatschappelijke kosten-batenanalyse' nodig zijn. Door het CPB en het PBL is hiervoor een 'leidraad' uitgebracht (G. Romijn \& G. Renes, Algemene leidraad voor maatschappelijke kosten-batenanalyse, CPB/PBL 2013). De leidraad presenteert acht stappen: (1) probleemanalyse; (2) vaststellen nulalternatief; (3) definitie beleidsalternatieven; (4) bepalen effecten en baten; (5) bepalen kosten; (6) varianten- en risicoanalyse; (7) opstellen overzicht van kosten en baten; (8) resultaten presenteren. De eerste stappen komen neer op een reconstructie van de beleidstheorie. In stap 6 komt de vraag naar de toekomstbestendigheid in beeld. 
een verstandige - maar politiek lastige - optie kunnen zijn. Koningin Elizabeth verwoordde dat mooi: 'To do nothing is often the best course of action - but history was not made by those who did nothing. ${ }^{43}$ 